\title{
Coded wire tagging of juvenile curimbatá, Prochilodus lineatus (Valenciennes, 1837) (Characiformes): mortality, tag retention, and growth
}

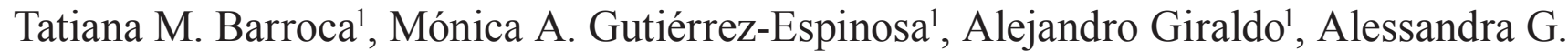 \\ Bedore $^{2}$ and Alexandre L. Godinho ${ }^{1}$
}

In recent decades, Brazilian hydroelectric reservoirs have been stocked with hundreds of millions of juvenile migratory fish, but almost no research on stocking has been conducted. In order to study stocking it is essential to tag the fish to be stocked. In this investigation we determined handling-induced mortality, tag retention rate, and absolute growth rate of hatcheryreared juvenile curimbatá (Prochilodus lineatus) tagged with coded wire tags (CWT), a tag widely used on stocked fish. We injected CWT into the dorsal musculature just below the first dorsal fin ray. Despite the need for frequent tag injector maintenance, this tagging location proved to be suitable for tagging juvenile curimbatá. We found no short-term mortality of juvenile curimbatá handled for CWT tagging, high retention rate for CWT ( $\geq 98.2 \%)$ even after $174 \mathrm{~d}$ of tagging, and no influence on absolute growth rate by CWT. We conclude that CWT is effective at tagging juvenile curimbatá, and we expect that it will also be effective for many other Brazilian fish species used for stocking.

Nas últimas décadas, reservatórios de hidrelétricas do Brasil foram estocados com centenas de milhões de jovens peixes migradores, mas quase nenhuma pesquisa sobre a estocagem foi conduzida. Para estudo da estocagem, etiquetar os peixes a serem estocados é essencial. Neste estudo, nós determinamos a mortalidade devido ao manejo, taxa de retenção da marca e taxa de crescimento absoluto de juvenis de curimbatá de cativeiro (Prochilodus lineatus) marcados com 'coded wire tag' (CWT), etiqueta amplamente utilizada em peixes estocados. Nós injetamos o CWT na musculatura dorsal logo abaixo do primeiro raio da nadadeira dorsal. Apesar de exigir manutenção frequente do injetor de CWT, esse local mostrou ser apropriado para a marcação de jovens de curimbatá. Não houve mortalidade de curto prazo nos juvenis manejados para marcação com CWT, a taxa de retenção do CWT foi elevada $(\geq 98,2 \%)$, mesmo após 174 dias da marcação. Além disso, o CWT não influenciou na taxa de crescimento absoluto dos peixes etiquetados. O CWT mostrou ser efetivo para marcar juvenis de curimbatá, e acreditamos que ele também o será para muitas outras espécies de peixes brasileiros utilizadas em estocagem.

Keywords: Neotropical fish, Passive tag, Stocking, Tag retention, Tagging mortality.

\section{Introduction}

The stocking of migratory fish species has been one of the major techniques used for fisheries restoration in hydropower reservoirs of Brazil. Hundreds of millions of fish have been stocked over the past three to four decades. In spite of this great effort, there have been few research on the success of the stocking (Vieira \& Pompeu, 2001; Agostinho et al., 2007; Agostinho et al., 2010), and most stocking has been done simply by trial and error with little scientific criteria.
Tagging stocked fish is essential for the evaluation of stocking as it allows the study of, among other things, stocking methods and movement, survival, and population structure of stocked fish (Adlerstein et al., 2007; Lantry et al., 2011; Pierce et al., 2011). Various types of tags have been used on stocked fish (Nielsen, 1992). Ideally, tags must have little impact on the individual fish, have high information content yet a low cost (Nandor et al., 2010; Haegen et al., 2012), and have high retention rate, such as the coded wire tag (CWT) (Brennan et al., 2005; Nandor et al., 2010; Pine et al., 2012).

${ }^{1}$ Centro de Transposição de Peixes, Universidade Federal de Minas Gerais, 31270-901 Belo Horizonte, Minas Gerais, Brazil. (TMB) tatiana.barroca@gmail.com, (MAGE) magutierreze@unal.edu.co, (AG) alejandro.giraldo.perez@gmail.com, (ALG) godinhoal@gmail. com (corresponding author)

${ }^{2}$ Fundação de Desenvolvimento da Pesquisa, Universidade Federal de Minas Gerais, 31270-901 Belo Horizonte, Minas Gerais, Brazil. (AGB) lebedore@terra.com.br 
The CWT was first used in early 1960s (Jefferts et al., 1963). It is a sophisticated and well-established tagging technique that is widely used for marking stocked fish (Nandor et al., 2010; Haegen et al., 2012). The small size of a CWT $(0.25 \times 1.10 \mathrm{~mm})$ allows it to be used on individual fish that are too small for other tagging methods (Nielsen, 1992; Haegen et al., 2012). Furthermore, the low cost and ease of application of the CWT have permitted large-scale experiments in stocking research (Brennan et al., 2007; Nandor et al., 2010).

The successful use of CWT in a stocking program depends on several aspects of the tagging procedure. The tagging procedures, which include the tagging site, tagging depth, and anesthesia, among other things, may influence handling-induced mortality, CWT retention rate, and fish growth (Nielsen, 1992; Fries, 2001; Munro et al., 2003; Ando et al., 2004; Brennan et al., 2007). The CWT has been injected in various tagging sites of different species of fish (Nielsen, 1992; Fries, 2001; Munro et al., 2003; Brennan et al., 2005, 2007). The retention rate of CWT is generally high (over 90\%), but it can be lower than $50 \%$ (Nielsen, 1992). Proper injection depth is very important for tag retention and depends on the size and species of the specimen being tagged (Northwest Marine Technology, 2003).

In South American rivers, Prochilodus is one of the most conspicuous, abundant and widely distributed migratory freshwater fish. Prochilodous is important for commercial and artisanal fisheries throughout its range (Welcomme, 1979; Bowen, 1983; Bonetto, 1986; Sivasundar et al., 2001; Castro \& Vari, 2004) and is one of the most commonly used fish for stocking Brazilian reservoirs (Agostinho et al., 2007). Curimbatá, Prochilodus lineatus (Valenciennes, 1837), is a medium-sized, potamodromous fish that occurs in rivers of Argentina, Brazil, Paraguay and Uruguay (Castro \& Vari, 2003).

In this study, we tagged hatchery-reared juvenile curimbatá, Prochilodus lineatus, with CWT to determine handling-induced mortality, tag retention rate, and influence of the tag on growth in experimental conditions. We determined short-term handling-induced mortality for different levels of handling intensity, tag retention rate for several injection depths and influence of CWT on longterm growth.

\section{Material and Methods}

We performed this study in the Estação Ambiental de Volta Grande (20¹'33"S 48¹3'14'W) of Companhia Energética de Minas Gerais (CEMIG) at Conceição das Alagoas, Minas Gerais, Brazil.

Juvenile production. To produce juvenile curimbatás, we used wild breeders maintained in a $1,400-\mathrm{m}^{2}$ excavated pond. In October 2010 we induced 24 breeders to spawn following the general procedures described in Sato et al. (1996). Four days after hatching, we transferred the free-embryos from incubators to six $200-\mathrm{m}^{2}$ outdoor concrete rearing tanks at a density of approximately 200 free-embryos per $\mathrm{m}^{2}$. We fed the larvae zooplankton for $15 \mathrm{~d}$ and then we fed them commercial fish food with $52 \%$ of crude protein.

Handling-induced mortality. We ran a short-term (13d) experiment to determine handling-induced mortality associated with CWT tagging of curimbatás. The completely randomized experimental design had four treatments based on handling intensity. We defined handling intensity as the number of steps used in the tagging of fish.

We transferred a sample of curimbatás from each of the six rearing tanks to a $200-\mathrm{m}^{2}$ outdoor crowding tank in November 2010. Thirteen days later we captured approximately 250 fish from the crowding tank and put them in four perforated stackable plastic boxes (50-70 fish per plastic box) of $57 \times 37 \times 23 \mathrm{~cm}$. We lined up the plastic boxes in a small flume (width $=47 \mathrm{~cm}$; water depth $=11 \mathrm{~cm}$ ) with running water (flow velocity $=0.3 \mathrm{~m} \cdot \mathrm{s}^{-1}$ ) from the Volta Grande Reservoir. We randomly selected the plastic boxes and subjected the contained fish to one of the following four treatments: (i) Lower intensity handling (control): We moved the plastic box from the flume to a container with $45 \mathrm{~L}$ of water. We captured fish individually and transferred them to a second plastic box, which was also in a container with $45 \mathrm{~L}$ of water. After transferring 50 fish, we placed the second plastic box in the flume; (ii) Intermediate intensity handling: We repeated the procedure of treatment (i) for 50 fish but, before we placed the fish into the second plastic box, we subjected them to both simulated CWT tagging and simulated checking for CWT presence. To simulate CWT tagging, we leaned fish against the CWT injector needle tip of a Northwest Marine Technology (NMT) Mark IV Tag Injector but we did not inject a CWT. We simulated checking for CWT presence using the NMT V-detector; (iii) Higher intensity handling: We repeated the procedure of treatment (ii) for 50 fish except that we injected the fish with a CWT in the dorsal musculature just below the first dorsal fin ray, and we checked for CWT presence. We excluded untagged fish from the experiment; (iv) Higher intensity handling with anesthesia: We repeated the procedure of treatment (iii) for 50 fish except that we anesthetized fish with clove oil diluted in water at 0.1 $\mathrm{mL} / \mathrm{L}$ before CWT tagging. We used clove oil because of its anesthetic qualities, it is easy to find, has safety margin for fish and no harmful effects for humans, and it is not unpleasant to handle (Roubach et al., 2005; Ross \& Ross, 2008; Cunha et al., 2010; Becker et al., 2013). Eugenol, the active ingredient of the clove oil, represents $70-90 \%$ of its weight (Becker et al., 2013).

After putting the fourth plastic box into the flume, we released the 50 fish of each treatment into a $6-\mathrm{m}^{3}$ outdoor concrete tank, randomly selected from 20 tanks, covered with a black $90 \%$ shade cloth cover. We then restarted the 
entire process by capturing approximately 250 specimens of curimbatás from the crowding tank. We repeated the whole process five times so that the experiment had four treatments, five replicates per treatment, and 50 fish per replicate. Each $6-\mathrm{m}^{3}$ tank represented a replicate.

We kept the fish in the $6-\mathrm{m}^{3}$ tanks for $13 \mathrm{~d}$. We fed fish commercial fish food with $45 \%$ of crude protein twice a day in the amount of 25 g.day ${ }^{-1}$ per tank. We checked each tank daily for dead fish. During the experiment, water temperature in the tank was $26-28^{\circ} \mathrm{C}$ and air temperature was $19-33{ }^{\circ} \mathrm{C}$, recorded for November 2010 at the nearest $(40 \mathrm{~km})$ weather station of the Instituto Nacional de Metereologia (station number 83577). Water in the tanks was from the Volta Grande Reservoir.

Tag retention and fish growth. To assess long-term tag retention and the influence of the tag on fish growth, we performed an experiment with a completely randomized design of four treatments: a control and three tag injection depths. We handled the fish in the same way as described for the handling-induced mortality experiment. Thus, after putting four perforated stackable plastic boxes $(57 \times 37 \times 23 \mathrm{~cm})$ lined up in the small flume with 50 70 fish, we randomly selected the plastic boxes and subjected all its fish to one of the following treatments: (a) No tag (control): We moved the plastic box from the flume to a container with $45 \mathrm{~L}$ of water. We captured fish individually and measured their standard length (SL). We then simulated both CWT tagging and checking for CWT presence following procedures described for treatment (ii). We then placed the fish in a second plastic box, which was also in a container with $45 \mathrm{~L}$ of water. We repeated treatment (a) for 40 fish and then we transferred the second plastic box to the flume; (b) $\mathrm{CWT}_{1}$ : We repeated the procedure of treatment (a) except we injected a CWT at a depth of $1 \mathrm{~mm}$ in the dorsal musculature just below the first dorsal fin ray; (c) $\mathrm{CWT}_{2}$ : We repeated the procedure of treatment (b) except we injected a CWT at a depth of 2 $\mathrm{mm}$; (d) $\mathrm{CWT}_{3}$ : We repeated the procedure of treatment (c) except we injected a CWT at a depth of $3 \mathrm{~mm}$.

After putting the fourth plastic box into the flume, we used the same procedure as in the handling-induced mortality experiment. We released fish of each treatment into a $6-\mathrm{m}^{3}$ outdoor concrete tank, randomly selected among 20 tanks, covered with black $90 \%$ shade cloth cover. We then restarted the entire process capturing 250 specimens of curimbatás from the crowding tank. We repeated this procedure five times. Thus, the tag retention and fish growth experiment included four treatments, five replicates per treatment, and 40 fish per replicate. Each $6-\mathrm{m}^{3}$ tank represented a replicate. The fish SL at the begging of the experiment ranged from 5.5 to $21.0 \mathrm{~cm}$.

We kept the fish in the 6- $\mathrm{m}^{3}$ tanks for $174 \mathrm{~d}$, from 9 Dec 2010 to 31 May 2011. We fed them commercial fish food with $45 \%$ of crude protein twice a day in the amount of 25 g.day $^{-1}$ per tank. We checked all tanks daily for dead fish. Temperature of the tank water was $20-29^{\circ} \mathrm{C}$ during the experiment, which was within the air temperature range $\left(15-33{ }^{\circ} \mathrm{C}\right)$ for the study period as recorded at weather station number 83577 of the Instituto Nacional de Metereologia. Water in the tanks was from the Volta Grande Reservoir.

We inspected the fish of all tanks twice. The first inspection was $97 \mathrm{~d}$ and the second inspection was $174 \mathrm{~d}$ after tagging. The duration of this experiment was similar to most other long-term CWT retention studies listed by Nielsen (1992). For inspection, we drained each tank and captured all of the fish. We then transferred the fish to a perforated stackable plastic box $(57 \times 37 \times 23 \mathrm{~cm})$, which we put in a flume with running water. For each fish, we measured the SL, checked for the presence of a CWT using the V-detector, and returned it to the original tank. We counted the number of fish in each tank to determine if any had escaped.

Data analysis. We determined the CWT retention rate for each tank for treatments $\mathrm{CWT}_{1}, \mathrm{CWT}_{2}$, and $\mathrm{CWT}_{3}$ at 97 and $174 \mathrm{~d}$ after tagging using the equation: CWT retention rate $=\mathrm{N}_{t} \cdot \mathrm{N}^{-1} \cdot 100$, where $\mathrm{N}_{t}=$ number of fish with a tag on the inspection day, and $\mathrm{N}=$ number of fish in the tank on the inspection day. We used the number of fish in the tank on the inspection day in an equation because of a possibility that fish had escaped. We used a KruskalWallis test to determine if $\mathrm{N}_{t}$ and CWT retention rates differed significantly among treatments. We used a nonparametric statistical test because $\mathrm{N}_{\mathrm{t}}$ and CWT retention rates was not normally distributed (Shapiro-Wilk test) and we were not able to normalize them even after using a series of transformations suggested by Sokal \& Rohlf (1995). No statistical analyses were necessary for the handling-induced mortality experiment.

We determined if fish absolute growth rate $\left(\mathrm{G}_{\mathrm{abs}}\right)$ differed among treatments using a one-way ANOVA with four levels (no tag, $\mathrm{CWT}_{1}, \mathrm{CWT}_{2}$, and $\mathrm{CWT}_{3}$ ) for the first and second inspections. We calculated $G_{\text {abs }}$ for each tank and inspection day using $\mathrm{G}_{\mathrm{abs}}=\left(\mathrm{SL}_{2}-\mathrm{SL}_{1}\right)$. $\Delta \mathrm{t}^{-1}$, where $\mathrm{SL}_{1}=$ initial median $\mathrm{SL}, \mathrm{SL}_{2}=$ final median $\mathrm{SL}$, and $\Delta \mathrm{t}=$ number of days between initial and final moments (Isely \& Grabowski, 2007). The $\Delta t$ was 97 for the first inspection and 77 for the second inspection. $G_{\text {abs }}$ were normally distributed for both inspections and all treatments (Shapiro-Wilk test).

In our experiment the experimental unit was the tank, not the individual fish, because fish kept in the same tank were not independent observations (Hurlbert, 1984). Therefore, we used median SL per tank in the calculation of $\mathrm{G}_{\text {abs }}$ to avoid pseudoreplication. We used median SL instead of mean SL because the frequency distribution of SL was not normal for some tanks even after transformation (Shapiro-Wilk test).

We performed all statistical analyses in SAS with 0.05 for the level of statistical significance. 


\section{Results}

Handling-induced mortality. No fish died due to handling in the $4 \mathrm{~h}$ between their capture in the crowding tank and their release in the $6-\mathrm{m}^{3}$ tank. Also, no fish died in the $6-\mathrm{m}^{3}$ concrete tanks during the $13 \mathrm{~d}$ of the experiment.

Tag retention and fish growth. The number of fish in the tanks decreased with time. This decrease was likely due to the escape of individuals because we found no dead fish during the experiment. At the end of the experiment, the number of fish per tank ranged from 28 to 40 (median $=35.0$ ), but there were no significant differences among treatments at the first (Kruskal-Wallis test; $P=0.98$ ) or at the second (Kruskal-Wallis test; $P=0.89$ ) inspections.

Kruskal-Wallis tests showed no significant differences in CWT retention rates among treatments at the first $(P$ $=0.37)$ and at the second $(P=0.89)$ inspections. At the first inspection, only fish of treatment CWT had no CWT. Mean tag retention rate for that treatment was $98.9 \%$. At the second inspection, fish from all treatments had lost tags. The mean tag retention rate was $98.9 \%$ for treatment $\mathrm{CWT}_{1}, 98.8 \%$ for treatment $\mathrm{CWT}_{2}$, and $98.2 \%$ for treatment $\mathrm{CWT}_{3}$ at the second inspection.

ANOVA showed that there was no significance difference in $\mathrm{G}_{\text {abs }}$ among treatments at the first $(P=0.60)$ and at the second $(P=0.59)$ inspections. Mean $\mathrm{G}_{\mathrm{abs}}$ ranged from 0.028 to $0.033 \mathrm{~mm} . \mathrm{d}^{-1}$ at the first inspection, and from 0.019 to $0.024 \mathrm{~mm} \cdot \mathrm{d}^{-1}$ at the second inspection (Fig. 1).

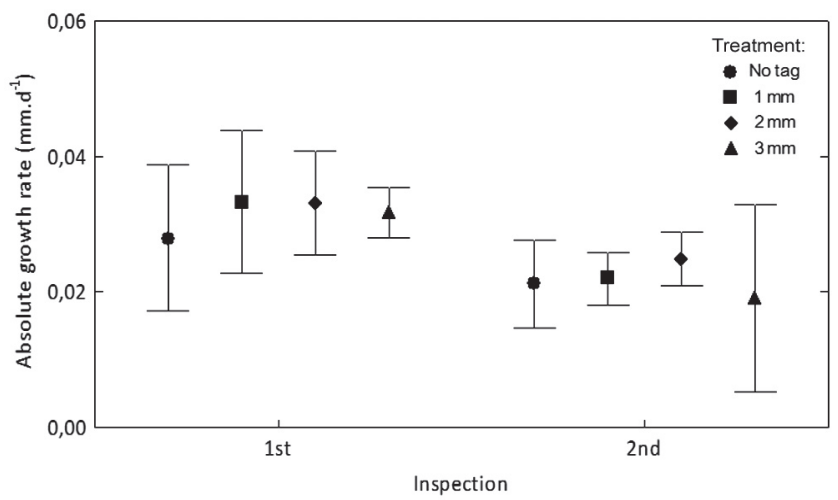

Fig. 1. Mean and $95 \%$ confidence interval of the absolute growth of juvenile curimbatá Prochilodus lineatus raised in concrete tanks at two inspection times for four treatments (no tag and coded wire tag injected at a depth of 1,2 , and $3 \mathrm{~mm})$.

\section{Discussion}

Our study showed that juvenile curimbatá tagged with CWT presented no short-term mortality and had high longterm tag retention rates. Therefore, the procedures we used for tagging curimbatá proved successful and we believe that it is very likely that CWT will be suitable for tagging many other species of Brazilian fish.
Juvenile curimbatá proved to be not susceptible to damage when handled for CWT tagging. We found no short-term mortality for any juvenile curimbatá handled for tagging. Other researchers have noted that most mortality associated with CWT tagging occurred within 2-3 days of tagging (Matlock et al., 1993; Burdick, 2011). We also found that short-term mortality was zero in both nonanesthetized and anesthetized fish. The non-anesthetized fish were a bit more difficult to net in the plastic box than anesthetized fish, but they were easier to hold by hand for tagging than the anesthetized fish because the anesthetic, which was an oil, made the anesthetized fish more slippery. If anesthesia is required, one might think of using another type of anesthetic.

Due to high tag retention and no negative influence to growth, use of CWT appears to be a viable option for tagging fish like juvenile curimbatá. The retention rate for 600 juvenile curimbatá that were freehand tagged was near $100 \%$ even after $174 \mathrm{~d}$, and the CWT did not affect growth of tagged fish. The retention rates found in this study were higher than those reported by other studies. Guy et al. (1996), for example, reported a retention rate of the 97\% for paddlefish (Polyodon spathula (Walbaum, 1792)), with a mean total length of $205 \mathrm{~mm}$ and tested for $51 \mathrm{~d}$. A retention rate of $90 \%$ was found for $45-125 \mathrm{~mm}$ (SL) red snapper (Lutjanus campechanus (Poey, 1860)) held for $150 \mathrm{~d}$ in $29-30^{\circ} \mathrm{C}$ water (Brennan et al., 2007), and $77 \%$ for paddlefish (with mean total length $240 \mathrm{~mm}$ ), tagged in the dorsal fin and held for $90 \mathrm{~d}$ in $23^{\circ} \mathrm{C}$ water (Fries, 2001). Marking fish with CWT has become a widely used practice in stocking programs because it is benign and has no effect on both fish growth and survival for a variety of species (Munro et al., 2003; Brennan et al., 2005; Brennan et al., 2007; Drenner et al., 2012).

The dorsal musculature just below the first dorsal fin ray is an appropriate location for CWT tagging of juvenile curimbatá. Injection of CWT has been done in various locations on the body of fish and optimal tag placement may differ among fish depending upon their species (Nielsen, 1992). In salmonids, the snout (nasal cartilage) is the preferred location (Oven \& Blankenship, 1993; Magnus et al., 2006; Adlerstein et al., 2007). In curimbatá, the snout is bony and may not be suitable for tagging. We injected the CWT into the dorsal musculature because tag application was easy, fast, and produced no noteworthy damage or injury to the fish. In fact, we found that using this location in curimbatá produced a high long-term retention rate $(\geq 98.2 \%)$. Others studies have also shown that fish tagged with CWT in the dorsal musculature next to the dorsal fin had high retention rates over the long term. For example, the retention rate was higher than $95 \%$ for small rainbow trout (Oncorhynchus mykiss (Walbaum, 1792)) after $60 \mathrm{~d}$ since tagging (Munro et al., 2003) and it was $90 \%$ for red snapper in a $150 \mathrm{~d}$ experiment (Brennan et al., 2007). One negative aspect of injecting CWT into the dorsal musculature of juvenile curimbatá is that the 
tag injector requires frequent maintenance because the needle removes scales from the fish and brings them into the injector. Removing the scales from the tagging location before tagging will solve this problem, but it will reduce the number of fish tagged per hour for the same crew size.

Injecting CWT to a depth of 2 or $3 \mathrm{~mm}$ in the dorsal musculature of juvenile curimbatá works better than 1 $\mathrm{mm}$. We did not find any difference in tag retention and growth among fish tagged at a depth of 1,2 , or $3 \mathrm{~mm}$, but we recommend not injecting CWT at $1 \mathrm{~mm}$ because at 2 and $3 \mathrm{~mm}$ the CWT penetrated the fish musculature in the first attempt more frequently than at $1 \mathrm{~mm}$. At a depth of $1 \mathrm{~mm}$, the scale thickness hinders injection of CWT, particularly in larger fish.

\section{Acknowledgments}

We thank the staff of the Estação Ambiental de Volta Grande for assistance during fieldwork, the biologist João de Magalhães Lopes for technical support, and the reviewers. This research was funded by the 'Peixe Vivo' program of Companhia Energética de Minas Gerais. MAGE had scholarship from Coordenação de Aperfeiçoamento de Pessoal de Nível Superior and ALG had a Conselho Nacional de Desenvolvimento Científico e Tecnológico fellowship.

\section{References}

Adlerstein, S. A., E. S. Rutherford, D. Clapp, J. A. Clevenger \& J. E. Johnson. 2007. Estimating seasonal movements of Chinook salmon in Lake Huron from efficiency analysis of coded wire tag recoveries in recreational fisheries. North American Journal of Fisheries Management, 27: 792-803.

Agostinho, A. A., L. C. Gomes \& F. M. Pelicice. 2007. Ecologia e manejo de recursos pesqueiros em reservatórios do Brasil. Maringá, Eduem, 501p.

Agostinho, A. A., F. M. Pelicice, L. C. Gomes \& H. F. Júlio Jr. 2010. Reservoir fish stocking: when one plus one may be less than two. Natureza \& Conservação, 8: 103-111.

Ando, D., M. Nagata, T. Kitamura \& Y. Shinriki. 2004. Evaluation of loss rate of coded-wire tags implanted into adipose eye tissue of masu salmon Oncorhynchus masou and effect on growth of tagged salmon. Fisheries Science, 70: 524-526.

Becker, A. G., M. A. Alves, L. O. Garcia, C. C. Zeppenfeld, T. V. Parodi, G. Maldaner, A. F. Morel \& B. Baldisserotto. 2013. Efficacy of eugenol and the methanolic extract of Condalia buxifolia during the transport of the silver catfish Rhamdia quelen. Neotropical Ichthyology, 11: 675-681.

Brennan, N. P., K. M. Leber \& B. R. Blackburn. 2007. Use of coded wire and visible implant elastomer tags for marine stock enhancement with juvenile red snapper Lutjanus campechanus. Fisheries Research, 83: 90-97.

Brennan, N. P., K. M. Leber, H. L. Blankenship, J. M. Ransier \& R. Debruler, Jr. 2005. An evaluation of coded wire and elastomer tag performance in juvenile common snook under field and laboratory conditions. North American Journal of Fisheries Management, 25: 437-445.
Bonetto, A. A. 1986. Fish of the Paraná System. Pp. 573-588. In: Davies, B. R. \& K. F. Walker (Eds.). The ecology of river systems. Dordrecht, DR W. Junk (Monographiae biological, v. 60).

Bowen, S. H. 1983. Detritivory in Neotropical fish communities. Environmental Biology of Fishes, 9: 137-144.

Burdick, S. M. 2011. Tag loss and short-term mortality associated with passive integrated transponder tagging of juvenile lost river suckers. North American Journal of Fisheries Management, 31: 1088-1092.

Castro, R. M. C. \& R. P. Vari. 2003. Family Prochilodontidae (Flannel mouth characiforms). Pp. 65-70. In: Reis, R. E., S. O. Kullander \& C. J. Ferraris Jr. (Orgs.). Check list of the freshwater fishes of South and Central America. Porto Alegre, Edipucrs.

Castro, R. M. C. \& R. P. Vari. 2004. Detritivores of the South American fish family Prochilodontidae (Teleostei: Ostariophysi: Characiformes): a phylogenetic and revisionary study. Washington, D. C., Smithsonian Books, 189p. (Smithsonian Contributions to Zoology, n. 622).

Cunha, M. A., C. C. Zeppenfeld, L. O. Garcia, V. L. Loro, M. B. Fonseca, T. Emanuelli, A. P. L. Veeck, C. E. Copatti \& B. Baldisserotto. 2010. Anesthesia of silver catfish with eugenol: time of induction, cortisol response and sensory analysis of fillet. Ciência Rural, 40: 2107-2114.

Drenner, S. M., T. D. Clark, C. K. Whitney, E. G. Martins, S. J. Cooke \& S. G. Hinch. 2012. A synthesis of tagging studies examining the behavior and survival of anadromous salmonids in marine environments. Plos One, 7: 1-13.

Fries, J. 2001. Retention of coded wire tags in four locations in juvenile paddlefish. North American Journal of Fisheries Management, 21: 962-966.

Guy, C. S., R. D. Schultz \& C. P. Clouse. 1996. Coded wire tag loss from paddlefish: a function of study location. North American Journal of Fisheries Management, 16: 931-934.

Haegen, G. V., H. L. Blankenship \& D. Knutzen. 2012. Advances in coded wire tag technology: meeting changing fish management objectives. Pp. 43-62. In: Mackenzie, J., B. Parsons, A. Seitz, R. K. Kopf, M. Mesa \& Q. Phelps. (Eds.). Advances in fish tagging and marking technology. Bethesda, Md: American Fisheries Society. (American Fisheries Society Symposium, 76).

Hurlbert, S. H. 1984. Pseudoreplication and the design of ecological field experiments. Ecological Monographs, 54: 187-211.

Isely, J. J. \& T. B. Grabowski. 2007. Age and growth. Pp: 187228. In: Guy, C. S. \& M. L. Brown (Eds). Analysis and interpretation of freshwater fisheries data. Bethesda, MD, American Fisheries Society.

Jefferts, K. B., P. K. Bergman \& H. F. Fiscus. 1963. A coded wire identification system for macro-organisms. Nature, 198: 460-462.

Lantry, B. F., R. O’Gorman, T. G. Strang, J. R. Lantry, M. J. Connerton \& T. Schaner. 2011. Evaluation of offshore stocking of lake trout in Lake Ontario. North American Journal of Fisheries Management, 31: 671-682.

Magnus, D. L., D. Brandenburger, K. F. Crabtree, K. A. Pahlke \& S. A. Macpherson. 2006. Juvenile salmon capture and coded wire tagging manual. Anchorage, Alasca Department of Fish and Game. 131p. (Special Publication, n. 06-31).

Matlock, G. C., L. W. McEachron, J. A. Dailey, P. A. Unger \& P. Chai. 1993. Short-term hooking mortalities of red drums 
and spotted seatrout caught on single-barb and treble hooks. North American Journal of Fisheries Management, 13: 186189.

Munro, A. R., T. E. Mcmahon, S. A. Leathe \& G. Liknes. 2003. Evaluation of batch marking small rainbow trout with coded wire tags. North American Journal of Fisheries Management, 23: 600-604.

Nandor, G. F., J. R. Longwill \& D. L. Webb. 2010. Overview of the coded wire tag program in the greater Pacific Region of North America. Pp. 5-20. In: Wolf, K. \& J. O’Neal (Eds.). Tagging, telemetry, and marking measures for monitoring fish populations. A compendium of new and recent science for use in informing technique and decision modalities. (Pacific Northwest Aquatic Monitoring Partnership (PNAMP) Special Publication series, 2010-002).

Nielsen, L. A. 1992. Methods of marking fish and shellfish. Bethesda, MD, American Fisheries Society, 208p.

Oven, J. H. \& H. L. Blankenship. 1993. Benign recovery of coded wire tags from rainbow trout. North American Journal of Fisheries Management, 13: 852-855.

Pierce, L. L., B. D. S. Graeb, D. W. Willis, J. S. Sorensen \& M. A. Pegg. 2011. Stocking success of paddlefish in Lake Francis Case, South Dakota: population characteristics and sport fishery potential. Transactions of the American Fisheries Society, 140: 1359-1369.

Pine, W. E, J. E. Hightower, I. G. Coggins, M. V. Lauretta \& K. H. Pollock. 2012. Design and analysis of tagging studies. Pp. 521-572. In: Zale, A. V., Parrish, D. L. \& Sutton, T. M. (Eds). Fisheries techniques, $3^{\text {rd }}$ ed. Bethesda, MD, American Fisheries Society.
Ross, L. G. \& B. Ross. 2008. Anaesthetic and sedative techniques for aquatic animals, $3^{\text {rd }}$ ed. Oxford, Blackwell Science, $222 p$.

Roubach, R., L. C. Gomes, F. A. L. Fonseca \& A. L. Val. 2005. Eugenol as an efficacious anaesthetic for tambaqui, Colossoma macropomum (Cuvier). Aquaculture Research, 36: 1056-1061.

Sato, Y., E. L. Cardoso, A. L. Godinho \& H. P. Godinho. 1996. Hypophysation parameters of the fish Prochilodus marggravii obtained in routine hatchery station conditions. Revista Brasileira de Biologia, 56: 59-64.

Sivasundar, A., E. Bermingham \& G. Ortí. 2001. Population structure and biogeography of migratory freshwater fishes (Prochilodus: Characiformes) in major South American Rivers. Molecular Ecology, 10: 407-417.

Sokal, R. R. \& F. J. Rohlf. 1995. Biometry: the principles and practice of statistics in biological research. $3^{\text {rd }}$ ed. New York, W. H. Freeman, 887 p.

Vieira, F. \& P. S. Pompeu. 2001. Peixamentos: uma alternativa eficiente? Ciência Hoje, 30: 28-33.

Welcomme, R. L. 1979. Fisheries ecology of floodplain rivers. London, Logman, 317p.
Submitted May 16, 2014

Accepted January 30, 2015 by Paulo Pompeu

Published June 30, 2015 